
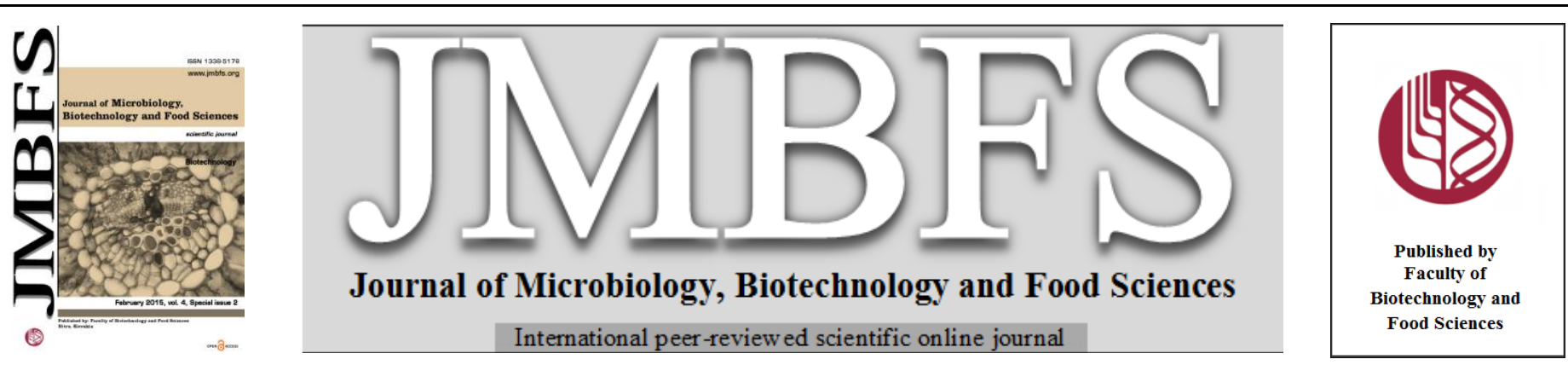

\title{
COMPARISON OF 2-DE PROTEOME MAPS OF WHEAT, RYE AND AMARANTH
}

\author{
Zdenka Gálová*, Eva Pálenčárová, Milan Chňapek, Želmira Balažová
}

\begin{abstract}
Address(es): prof. RNDr. Zdenka Gálová, CSc.,
Department of Biochemistry and Biotechnology, Faculty of Biotechnology and Food Sciences, Slovak Univesity of Agriculture, Trieda A. Hlinku 2, SK-949 76 Nitra, Slovak Republic
\end{abstract}

*Corresponding author: Zdenka.Galova@uniag.sk

doi: 10.15414/jmbfs.2015.4.special2.7-10

\begin{abstract}
ARTICLE INFO
\section{ABSTRACT}

Received 3. 12. 2014

Revised 5. 1. 2015

Accepted 15. 1.2015

Published 2. 2. 2015

The protein maps of wheat (Triticum aestivum L.), cv. Brea; rye (Secale cereale L.), cv. Oklon and amaranth (Amaranthus sp.) cv. Plaisman were obtained by performing 2-DE over a broad $\mathrm{pH}$ range $(\mathrm{pH} 3-11 \mathrm{NL})$ to obtain total protein profiles. Focussing on the gluten fraction, as it is the major trigger for Celiac disease, proteins were separated with a basic pI over a narrow $\mathrm{pH}$ range of $\mathrm{pH}$ 6-11 Putative identifications of proteins were determined using current literature. The overall spot pattern from wheat over $\mathrm{pH} 6-11$ was identified as gamma-gliadins ( pI 8-10, $\left.\mathrm{M}_{\mathrm{r}} \mathrm{S} 28-30,000 \mathrm{Da}\right)$ ), alpha/beta-gliadins ( pI 6.5-7.5, $\left.\mathrm{M}_{\mathrm{r}} \mathrm{s} 25-35,000 \mathrm{Da}\right)$ and gluten proteins (pI 6-10, $\mathrm{M}_{\mathrm{r}} \mathrm{s} 35-60,000 \mathrm{Da}$.). The rye had a higher number of abundant groups visible over a broad range ( 6-200,000 Da, pI 4-9).

Regular article Comparison of rye to wheat protein maps showed that each cereal had completely different spot patterns in the LMW region of the gels ( $<14,000 \mathrm{Da}$ ), but similarities were observed in the HMW and MMW regions. This is especially evident in the $\mathrm{pH}$ 6-11 gels. Amaranth has many proteins focussed between $\mathrm{pH} 3-11$. Fewer proteins were observed for the $\mathrm{pH}$ 6-11 gel, especially in the HMW weight region of the gel. This is due to the fact that the pseudocereals are a botanically different species compared to cereal grasses, and even if they are rich in protein, unfavourable fractions are not present or are only available in small amounts.
\end{abstract}

Keywords: Amaranth, buckwheat, 2-DE protein maps, celiac disease

\section{INTRODUCTION}

Celiac disease (CD) is characterized by small-intestinal mucosal injury and nutrient malabsorbtion in genetically susceptible individuals in response to the dietary ingestion of wheat gluten and similar proteins in barley and rye. CD constitutes permanent intolerance to dietary wheat proteins, especially gluten. The protein intolerance of $\mathrm{CD}$ is mediated by the enhanced gastrointestinal mucosal immune system, which is activated At the present time, perspective group of crops for the gluten-free diet for celiac disease appear to be so called pseudocereals (Wieser and Koehler, 2008).

Some cereals (rice, maize and others) and pseudocereals (amaranth, buckwheat and quinoa), rich in proteins, do not contain gluten, which is the main cause of celiac disease. It is known that alcohol soluble prolamins predominate in cereals. Globulins are predominant in legumes and other dicotyledones. Recent findings suggest that Western diets based on highly palatable foods are likely to be much less satiating than more ethnic foods or those typical of less developed countries. In particular, some alternative crops (e.g. buckwheat, oat, barley, spelt, rye, quinoa, amaranth) seem to be of great nutritional interest and to represent important recipes for healthier and typical regional foods (Gorinstein et al., 2007). Therefore, in the last decade, the use of pseudocereals was increased not only in special diets for people allergic to cereals, but also in healthy diets. Comparative protein studies of cereals and pseudocereals are important, especially in cases of cereal protein allergy when pseudocereal substitution is unavoidable.

Two-dimensional gel electrophoresis (2-DE) is one of the most powerful and common tools for separation and fractionation of complex protein mixture extracted from tissues, cells, and other biological specimens. It is an orthogonal technique that allows separation of thousands of proteins in one gel and in a two tandem electrophoretic steps where a major proportion of proteins can be resolved for further analysis (Weiss and Görg, 2007; Vensel et al., 2014).

The objectives of our work was to prepare and compare two-dimensional gel electrophoresis protein maps of wheat, rye and amaranth from the point of view detection of coeliac active proteins.

\section{MATERIAL AND METHODS}

\section{Plant material}

Seeds of wheat (Triticum aestivum L.) cv. Brea, rye (Secale cereale L.) cv. Oklon, amaranth (Amaranthus sp.) cv. Plaisman were used for analyses. Seeds from the Gene Bank of the Research Institute of Plant Production, Piešt'any (Slovak Republic) were obtained and by CU Mill, (Lionhill Company a.s.) were milled to a homogenous flour.

Methods

Two - dimensional gel electrophoresis (2-DE)

\section{Samples preparation}

Proteins from the flour were extracted by adding $1 \mathrm{ml}$ of buffer [ $250 \mu 1$ DTT (28 mg.ml ${ }^{-1}$ ), $12.5 \mu 1$ IPG buffer (carrier ampholytes) and $237.5 \mu 1$ ultra-pure water to $2 \mathrm{ml} \mathrm{IPG} \mathrm{rehydration} \mathrm{buffer} \mathrm{(} 7$ mol. $\mathrm{dm}^{-3}$ urea, $2 \mathrm{~mol}^{-\mathrm{dm}^{-3}}$ thiourea, $2 \%$ CHAPS)] to $50 \mathrm{mg}$ of flour. The samples were then wheel-mixed for $1 \mathrm{~h}$, RT and then centrifuged $3 \mathrm{~min}, 9,000 \times \mathrm{g}$, RT. The protein content of the supernatant (SN) was estimated by Coomassie Plus protein assay (Thermo Scientific, Pierce, UK) (based on the Bradford assay) and samples were stored at $-20{ }^{\circ} \mathrm{C}$ until use. The protein content of the oat extract was insufficient, so the Compact-Able ${ }^{\mathrm{TM}}$ Protein Assay Preparation Reagent Set (Thermo Scientific, Pierce, UK) was used to precipitate the protein, which was then re-suspended in the extraction buffer as described previously.

$\boldsymbol{I}^{\text {st }}$ Dimension - Isoelectric focussing (IEF): Immobilised $\mathrm{pH}$ gradient (IpG) strips (GE Healthcare, Amersham UK), $7 \mathrm{~cm}, \mathrm{pH}$ 3-11 NL and pH 6-11, were used for the first dimension. Strips were hydrated $\mathrm{O} / \mathrm{N}$ at $20^{\circ} \mathrm{C} 125 \mu 1$ rehydration buffer $\left[7\right.$ mol.. $\mathrm{dm}^{-3}$ urea; 2 mol. $\mathrm{dm}^{-3}$ thiourea, $2 \%$ w/v CHAPS; 0.5 mol.. $\mathrm{dm}^{-3}$ DTT; relevant $\mathrm{pH}$ range IPG buffer; $0.001 \% \mathrm{w} / \mathrm{v}$ bromophenol blue] containing $\sim 40 \mu \mathrm{g}$ protein of sample. Focussing was performed at $20^{\circ} \mathrm{C}$, current $50 \mu \mathrm{A} \mathrm{per}$ strip $(300 \mathrm{~V} 30 \mathrm{~min} 0.2 \mathrm{kVh} ; 1000 \mathrm{~V} 30 \mathrm{~min}, 0.3 \mathrm{kVh} ; 5000 \mathrm{~V}, 1 \mathrm{~h} 20 \mathrm{~min}, 4.0$ $\mathrm{kVh} ; 5000 \mathrm{~V}, 25 \mathrm{~min}, 2.0 \mathrm{kVh}$ ). Focussed IPG strips were stored at $-80{ }^{\circ} \mathrm{C}$ until required.

$2^{\text {nd }}$ Dimension - SDS PAGE: Focussed IPG strips were equilibrated in trisacetate equilibration buffer $\left[0.122 \mathrm{~mol}^{-\mathrm{dm}^{-3}}\right.$ tris-acetate containing $0.5 \% \mathrm{w} / \mathrm{v}$

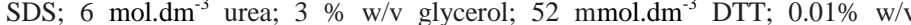
Bromophenol blue]. After 30 min strips were derivatised in the dark with 0.14 mol. $\mathrm{dm}^{-3}$ iodoacetamide in equilibration buffer for a further $30 \mathrm{~min}$. Strips were then transferred to $1 \mathrm{~mm}, 4-12 \%$ Bis-Tris Zoom ${ }^{\mathrm{TM}}$ gels for the second dimension. Gels were run at $200 \mathrm{~V}$ and $100 \mathrm{~W}$ per gel for 35 min using 1 x MES SDS Running Buffer. Gels were fixed $\mathrm{O} / \mathrm{N}$ in $40 \% \mathrm{v} / \mathrm{v}$ methanol containing 10 $\%$ w/v TCA before staining with SYPRO Ruby Stain (Invitrogen, UK) in the dark $\mathrm{O} / \mathrm{N}$. After de-staining $\mathrm{O} / \mathrm{N}$ with $10 \% \mathrm{v} / \mathrm{v}$ methanol and $6 \% \mathrm{TCA}$, gels were imaged using a high-resolution molecular imager (PHAROS FX ${ }^{\mathrm{TM}}$ Plus, 
Bio Rad, UK). Imaged gels were returned to de-stain solution and stored in the dark at $4{ }^{\circ} \mathrm{C}$ until required.

\section{RESULTS AND DISCUSSION}

The gluten fraction of wheat flour is the main cause of the development of Coeliac disease. Determination of individual gluten peptides responsible for toxicity and immunogenecity is very difficult because, gluten is a mixture of proteins that are closely related (Parnell and Ciclictira, 1999). Initially, the toxicity of a well-defined group of $\alpha / \beta$-type gliadins, called $\alpha$-gliadin, was established, by means of instillation into the small intestine, followed by biopsy (Wieser and Koehler, 2008). The toxicity of $\alpha$-gliadin was subsequently confirmed by in vitro organ culture tests. Later, both in vivo and in vitro studies implicated all gliadin fractions, with decreasing activity from $\alpha$ - to $\omega$-gliadins, as instrumental in causing disease (Parnell and Ciclictira, 1999). The $\alpha$-gliadin is the most toxic fraction and this protein has a relative low molecular weight of approximately $30 \mathrm{kDa}$ (Parnell and Ciclictira, 1999; Wieser and Koehler, 2008).).

Protein separation is a core part of proteomics analysis and two-dimensional ge electrophoresis is a basic and fundamental procedure to separate each protein from protein complexes. 2-DE with immobilized $\mathrm{pH}$ gradients (IPGs) combined with protein identification by mass spectrometry (MS) is currently the workhorse for proteome analysis. Two-dimensional gel electrophoresis has frequently been used to characterize the diversity of protein components. The first dimensiona involves isoelectric focusing, in which proteins are fractionated across a specific $\mathrm{pH}$ range using commercially available $\mathrm{pH}$ gradient strips. The seconddimension fractionation resolves the proteins on the basis of molecular mass, using sodium dodecyl sulfate polyakrylamide gel electrophoresis (SDS-PAGE) (Skylas et al., 2000). The aim of our study was to evaluate the electrophoretic profiles of storage proteins of wheat, rye and amaranth seeds, which were obtained by two-dimensional electrophoresis.
Our results showed, that many proteins of wheat were focussed over $\mathrm{pH} 3-11$ (figure 1) between $6,000-120,000 \mathrm{Da}$ and the most abundant proteins were observed in the basic region of the gel; including three abundant proteins visible at approximately pI 7, $14,000 \mathrm{Da}$ (figure 1ii). These corresponded to trypsin/alpha-amylase inhibitors previously identified from the soluble fraction of wheat dough (Salt et al., 2005), as well as in immature wheat-grain endosperm proteins (Skylas et al., 2000). A larger abundant protein group was visible between 36-55,000 Da (figure 1i) and these proteins were resolved at the correct mass and pI range for gluten, previously identified by Skylas et al., (2000); where a group of high molecular weight glutenin subunits with pI 5.5-6.5, 66-100,000 $\mathrm{Da}$. and a group of omega gliadins with pI 5.0-6.0, 45-55, $000 \mathrm{Da}$ were observed using 2-DE. This group is particularly important for celiac disease, so these basic proteins were separated over a narrower range of $\mathrm{pH}$ 6-11 (figure 1iii). It was obvious that these proteins were highly abundant as they were much better resolved and well-defined spots were achieved over this basic $\mathrm{pH}$ range $(\mathrm{pH} 6-9)$ These proteins formed a distinct pattern of spots allowing comparison with 2-D maps of other cereal proteins. It was also observed, that the alpha-amylase/ trypsin inhibitors were better resolved in the basic region (figure 1iv). Although these proteins are not linked to celiac disease, they have been reported to trigger bakers asthma and have been linked to food allergy (James et al., 1997). The overall spot pattern from wheat (cv. Brea) over pH 6-11 (figure 1) was partially similar to those reported by Skylas et al. (2000), Mamone et al. (2005) and Akagawa et al. (2007). These included proteins identified as gamma-gliadins ( pI 8-10, $\left.\mathrm{M}_{\mathrm{r}} \mathrm{s} 28-30,000 \mathrm{Da}\right)$, alpha/beta-gliadins ( pI 6.5-7.5, $\mathrm{M}_{\mathrm{r}} \mathrm{s} 25-35,000$ Da) and gluten proteins (pI 6-10, $\mathrm{M}_{\mathrm{r}} \mathrm{s} 35$ - 60, $000 \mathrm{Da}$.). A cluster of polypeptides resolved at the end of $\mathrm{pH}$ 6-11 gel may be tritin ( pI 9.5-10, $\left.\mathrm{M}_{\mathrm{r}} \mathrm{s} 25,000 \mathrm{Da}\right)$ (figure $1 \mathrm{v}$ ), a protein synthesis inhibitor, which was previously identified by MALDI-MS (Salt et al., 2005).
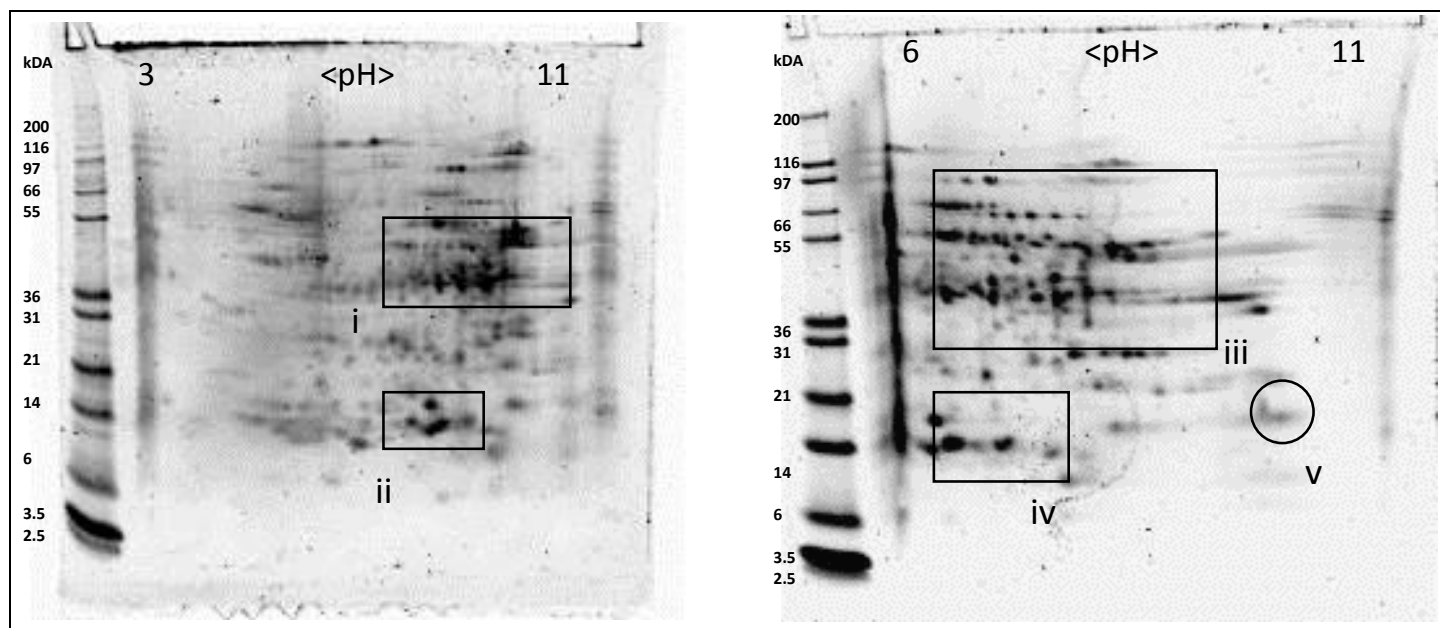

Figure 1 Protein maps of wheat (cv. Brea)

The 2-DE protein maps in figure 2 represents the proteins of mature rye seed flour. Although rye belongs to a similar tribe as wheat quite big differences were observed for the 2-DE protein map of rye. The other cereals had a small number of abundant groups, mainly focussed in the basic regions of the gels however, rye had a higher number of abundant groups visible over a broad range ( 6-200,000 Da, pI 4-9). Highly abundant proteins visible at approximately 55,000 Da, pI 6-9 (figure 2i) and 40,000 Da, pI 6-9 (figure 2ii) were observed as over-lapping spots forming an isoelectric streak. These proteins were running at the correct $\mathrm{Mr}$ and $\mathrm{pI}$ observed for high-molecular-weight glutenin subunits (HMW) and low-molecular-weight glutenin subunits (LMW) of glutenin (Gellrich et al., 2003). Rocher et al. (1996) identified $\gamma$ - and $\omega$-type secalins together with two low molecular mass glycoproteins as the major coeliac immunoreactive proteins from a chloroform/methanol soluble extract from rye endosperm. One $\omega$-type secalins of $40 \mathrm{kDa}(\omega 1-40)$; three $\gamma$-type secalins one of
$70 \mathrm{kDa}(\gamma-70)$ and two of $35 \mathrm{kDa}(\gamma-35)$; as well as two low molecular mass glycoproteins of 15 and $18 \mathrm{kDa}$, all exhibit coeliac serum antigenicity. Coeliac immunogenic secalins, $\gamma-70, \gamma-35$ and $\omega 1-40$ indicated molecular masses of 71,457, 32,240 and 39117 Da respectively. There is absence of information about rye proteins, especially of those obtained by 2-D electrophoresis.

When proteins were separated over a narrow $\mathrm{pH}$ range of $\mathrm{pH} 6-11$, we found some proteins that were at similar $\mathrm{pI}$ and $\mathrm{Mr}$ to protein spots separated on wheat 2-DE gels, including isoelectric streaks of protein spots in the region of $55,000 \mathrm{Da}, \mathrm{pI}$ 6-7 (figure 2a) and in the region of 45-50,000 Da, pI 6-8 (figure $2 \mathrm{~b}$ ). Comparison of rye to wheat (figure 1) protein maps showed that each cerea had completely different spot patterns in the LMW region of the gels $(<14,000$ Da), but similarities were observed in the HMW and MMW regions. This is especially evident in the $\mathrm{pH}$ 6-11 gels. 


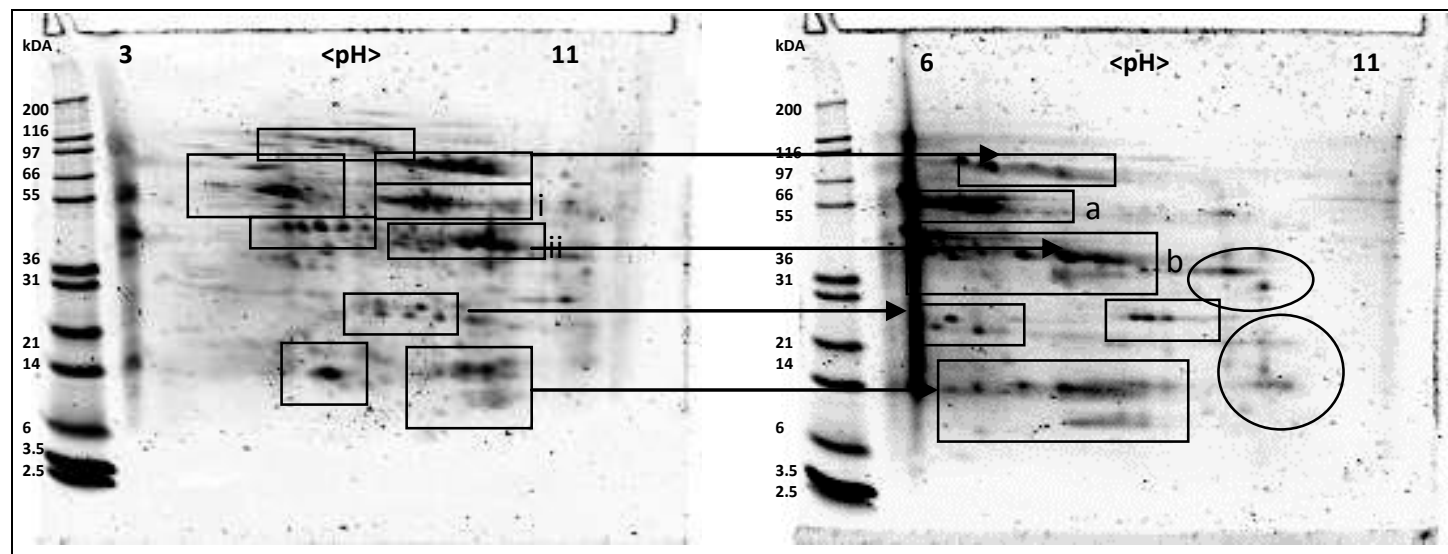

Figure 2 Protein maps of rye (cv. Oklon)

The 2-DE protein maps in figure 3 represents the proteins of mature amaranth seed flour. First, 2-DE - gels with $\mathrm{pH}$ 3-11 were run, that were followed by 2-DE - gels with $\mathrm{pH}$ 3-11. Upon initial observation, amaranth has many proteins focussed between $\mathrm{pH} 3-11,25,000-200,000 \mathrm{Da}$ (figure 3) with areas of abundant proteins at: 14, 000-31,000 Da, pI 8-9 (Figure 3v), 36, $000 \mathrm{Da}$ pI 4-6 (figure 3vii), 55, 000-66, $000 \mathrm{Da}, \mathrm{pI}$ 6-7 (figure 3viii); this could be 11S globulin which has a theoretical $\mathrm{pI} 6.53, \mathrm{M}_{\mathrm{r}} \mathrm{s} 55,064 \mathrm{Da}$, and belongs to the $11 \mathrm{~S}$ seed storage protein family. Fewer proteins were observed for the pH 6-11 gel, especially in the HMW weight region of the gel where storage proteins (figure $3 \mathrm{i}$, 3ii) were observed for the cereals. This is due to the fact that the pseudocereals are a botanically different species compared to cereal grasses, and even if they are rich in protein, unfavourable fractions are not present or are only available in small amounts.

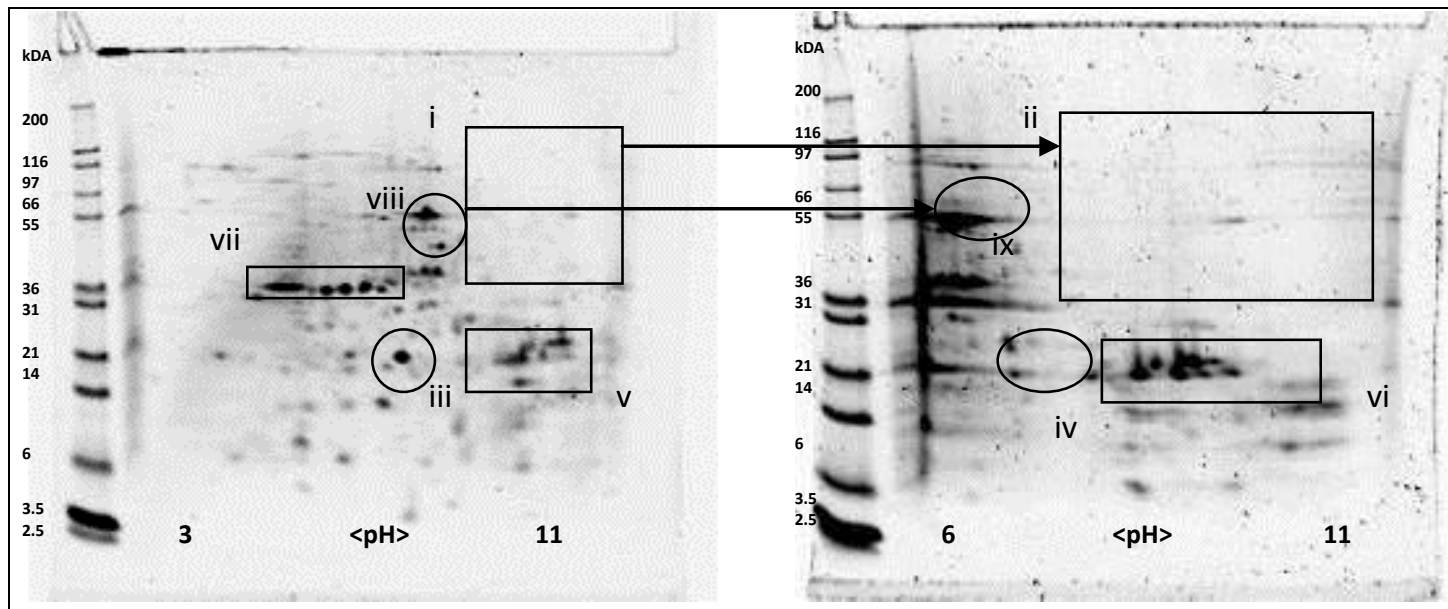

Figure 3 Protein maps of amaranth (cv. Plainsman)

We can notice big differences especially between protein composition of cereals and pseudocereals (Pálenčárová and Gálová, 2010). On the pseudocereal proteins maps we miss protein pattern in area with molecular mass ranging from 40 to $200,000 \mathrm{Da}$ and $\mathrm{pI}$ ranging from 9-11, which are visible on cereal proteins maps and corresponded to gluten protein these are supposed triggers of celiac disease. This showed differences between species that also are related to differences in functional properties. There is not enough information about 2-DE of pseudocereals available in the literature so it was difficult to assign any likely protein identifications to the gels.

Gorinstein et al. (2005) analysed the relationship between dicotyledons (amaranth, quinoa, fagopyrum, soybean) and monocots (sorghum and rice), based on protein analyses and their use as substitution of each other and found similarities between these plants, which could make them a substitute of each other as well as for cereals. They reported that combination and substitution of cereals by pseudocereals lead to nutritional foods and can prevent allergy. Food components may be promoters of positive metabolic mechanisms; Gupta (2004) says that a combination of cereals, pseudocereals and soybean provides proteinrich ingredients resulting in higher nutritive value.

\section{CONCLUSION}

Our work deals with comparison of wheat, rye and amaranth 2-DE proteins maps with aim to find out differences between then. A two-dimensional gel electrophoresis (2-DE) map of roughly 40 spots was obtained by submitting the $70 \%$ alcohol-soluble crude protein extract to isoelectric focusing on immobilized $\mathrm{pH}$ gradient strips across two $\mathrm{pH}$ gradient ranges, i.e., 3-10 or $\mathrm{pH}$ 6-11 and to sodium dodecyl sulfate-polyacrylamide electrophoresis in the second dimension. We determined similarity between the chemical properties proteins of cereals wheat, rye and pseudocereals amaranth, where most of the extracted proteins have $\mathrm{pI}$-values ranging from 5 to 10 and the molecular masses ranging from 14 to $55,000 \mathrm{Da}$. Amaranth did not show the presence of celiac active proteins.

Acknowledgments: This work was co-funded by European Community under project no 26220220180: Building Research Centre „AgroBioTech" (50\%) and VEGA project No. 2/0066/13 (50 \%).

\section{REFERENCES}

AKAGAWA, M., HANDOYO, T., ISHII, T., KUMAZAWA, S., MORITA, N., SUYAMA, K. 2007. Proteomic Analysis of Wheat Flour Allergens. Journal of Agriculture and Food Chemistry, 55(17), 6863-6870.

GELLRICH, C., SCHIEBERLE, P., WIESER, H. 2003. Biochemical characterisation and quantification of the storage protein (secalin) types in rye $\begin{array}{llll}\text { flour. Cereal Chemistry, } & \text { 80, } & 102-109\end{array}$ http://dx.doi.org/10.1094/CCHEM.2003.80.1.102.

GORINSTEIN, S., DRZEWIECKI, J., DELGADO-LICON, E., PAWELZIK, E., AYALA, A. L. M., MEDINA, O. J., HARUENKIT, R., TRAKHTENBERG, S. 2005. Relationship between dicotyledone-amaranth, quinoa, fagopyrum, soybean and monocots- sorghum and rice based on protein analyses and their use as substitution of each other. Journal of European Food Research and Technology, 221, 69-77. http://dx.doi.org/10.1007/s00217-005-1208-2.

GUPTA, H. O. 2004. Improving the nutritional quality of maize after suplementation with processed soybean. Journal of Food Science and Technology, 41, 167-170.

JAMES, J. M., SIXBEY, J. P., HELM, R. M., BANNON, G. A., BURKS, A.W 1997. Wheat $\alpha$-amylase inhibitor: A second route of allergic sensitization. 
Journal of allergy and Clinical Immunology, 99(2), 239-244. http://dx.doi.org/10.1016/S0091-6749(97)70103-9.

MAMONE G, ADDEO F, CHIANESE L, DI LUCCIA A, DE MARTINO A, NAPPO A, FORMISANO A, DE VIVO P, FERRANTI P. 2005 Characterization of wheat gliadin proteins by combined two-dimensional gel electrophoresis and tandem mass spectrometry. Proteomics, 5(11), 2859-65. http://onlinelibrary.wiley.com/doi/10.1002/pmic.200401168/pdf

PALENČÁROVÁ, E., GÁLOVÁ, Z. 2010. Detection of celiac active proteins by electrophoretic and immunochemical methods [CD-ROM]. Potravinárstvo, 4 485-490.

PARNELL, N. D. J., CICLICTIRA, P. J. 1999. Rerview article: celiac disease and its management. Alimentary Pharmacology and Therapeutics, 13, 1-13. http://onlinelibrary.wiley.com/doi/10.1046/j.1365-2036.1999.00448.x/pdf.

ROCHER, A., CALERO, M., SORIANO, F., MÉNDEZ, E. 1996. Identification of major rye secalins as coeliac immunoreactive proteins. Biochimica et Biophysica Acta (BBA) - Protein Structure and Molecular Enzymology, 1259(1), 13-22. http://www.sciencedirect.com/science/article/pii/0167483895002693.

SALT, L. J., ROBERTSON, J. A., JENKINS, J. A., MULHOLlAND, F., MILLS, E. N. C. 2005. The identification of foam-forming soluble proteins from wheat (Triticum aestivum) dough. Proteomics, 5, 1612-1623. http://onlinelibrary.wiley.com/doi/10.1002/pmic.200401035/pdf.

SKYLAS, D. J., MACKINTOSH, J. A., CORDWELL, S. J., BASSEAL, D. J.,

WALSH, B. J., HARRY, J., BLUMENTHAL, C., COPELAND, L., WRIGLEY, C. W., RATHMELL, W. 2000. Proteome approach to the characterisation of protein composition in the developing and mature wheat-grain endosperm Journal of Cereal Science, 32, 169-188.

VENSEL WH, TANAKA CK, ALTENBACH SB. 2014. Protein composition of wheat gluten polymer fractions determined by quantitative two-dimensional gel electrophoresis and tandem mass spectrometry. Proteome Sci. 12(1), 8. doi 10.1186/1477-5956-12-8.

WIESER, H., KOEHLER, P. 2008. The Biochemical Basis of Celiac Disease Cereal Chemistry, 85(1), 1-13. http://dx.doi.org/10.1094/CCHEM-85-1-0001.

WEISS W, GÖRG A. 2007. Two-dimensional electrophoresis for plant proteomics. Methods in Molecular Biology, 355, 121-43. 